\title{
Negative Research on the Obligation of Shareholders to Accelerate the Expiration
}

\author{
Zhang Ke \\ Political Theory Department, Nanyang Institute of Technology, China \\ zhangke1981727@126.com
}

Keywords: Shareholder contribution obligation, Accelerated expiration, theoretical analysis, Relief mechanism

\begin{abstract}
The amendment of the "Company Law" in December 2013 marked the completion of the company's capital system reform. In the case of non-bankruptcy, when the company is unable to pay off the debt, can the company' s creditors request the shareholders who have not made the capital contribution period to fulfill their capital contribution obligations in advance? At present, there is no uniform refereeing rule in legislation or legal interpretation, which leads to a large number of different cases in the judicial trial practice, cannot be effectively alleviated and curbed. It is clear that the author's point of view is that in the case of non-bankruptcy, the creditor cannot request the shareholder's contribution obligation to expedite the expiration, and points out the legal basis on which it is based. The author's point is to solve the problem, focusing on the rights relief mechanism in which the creditor cannot request the shareholders' contribution obligation to accelerate the expiration in the non-bankruptcy situation. This series of relief mechanisms mainly includes the company's accelerated expiration of claims in special circumstances, the introduction of bankruptcy settlement system, the establishment of court inquiry procedures, the improvement of the collection system, and the improvement of the company's credit disclosure system.
\end{abstract}

In 2013, the company's capital system reform, the funding period is completely agreed by the shareholders themselves, resulting in a very long period of time, especially the grace period of several decades and one hundred years, which is not user-friendly for the creditor's realization of creditor's rights. However, the "Company Law" and its judicial interpretation left a gap in the shareholder's responsibility for capital contribution in this case, which led to judicial practice and academic circles who were confused about whether the non-bankruptcy stage could expedite the expiration. The author believes that the company law path, the contract law path, the tort law path, and the execution procedure path lack legality and rigor. Therefore, the shareholder's obligation to accelerate the expiration of the system cannot be applied in the case of non-bankruptcy. There is a certain legal basis for shareholders' capital contribution obligations not to expedite the expiration.

\section{The principle of equality of creditor's rights.}

Taiwanese scholar Wang Zejian believes that several claims, regardless of their occurrence, coexist in the same position, unless the law specifically stipulates. The principle of equality of creditor's rights in China's private law is embodied in: First, the two or more claims with the same content can be different in the effectiveness of the creditor's rights, regardless of the number of creditor's rights, the amount of the creditor's rights, and the reasons for the occurrence. Completely 
equal. Second, several creditors of the same debt to which the liquidation period has expired have equal rights to claim property. The legislative purpose of the bankruptcy law is to achieve a fair settlement of each claim. According to the provisions of Article 35 of the Enterprise Bankruptcy Law, the term of the shareholders' capital contribution is deprived in the bankruptcy proceedings in order to guarantee the fair compensation of all creditors. According to the "Company Law", if the company is insolvent, and finally enters the bankruptcy liquidation procedure, then the creditor needs to declare the debt. After the bankruptcy property of the company repays the tax creditor's right and the labor creditor's right, if there is surplus property, the ordinary creditor's right of other creditors must be paid off in proportion. Assume that the company has not entered the bankruptcy liquidation stage, giving the creditor shareholders the capital contribution obligation to speed up the claim for expiration. If the company's total assets are insufficient to pay off all the debts, among the many corporate creditors, there will be a situation in which the first lawsuit will be paid first. If the company discloses the inability to pay off the debt to a specific creditor, the creditor immediately filed a lawsuit with the court in accordance with the provisions of the third paragraph of Article 13 of the Judicial Interpretation of the Company Law, so that all of its claims are fully settled. Other creditors who did not file a claim for compensation had to pay off in the same proportion after the company entered the bankruptcy proceedings as an ordinary creditor. The result of this is that creditors who fail to file a lawsuit in accordance with the law of the third paragraph of Article 13 of the Judicial Interpretation of the Company Law will face a huge risk of being unable to be reimbursed due to the reduction of the company's liability property. Therefore, pre-liquidation of individual creditors clearly undermines the equal rights of compensation of other creditors of the company.

\section{The efficiency principle of commercial law.}

The famous American scholar Posner is a representative of the School of Economic Analysis. He believes that "the law itself (including its norms, procedures and systems) is to promote the realization of benefits as an important goal." The most intuitive manifestation of efficiency is to create the greatest benefits at the lowest cost. Then the company's capital system should be set up to facilitate financing and improve financing efficiency. Investors can flexibly arrange for the company's capital to effectively capture the fleeting business opportunities. Paying attention to protecting the benefits of shareholders' investment deadlines can stimulate a large number of social workers to invest in entrepreneurship, which is the embodiment of the transaction efficiency concept. It is a violation of the efficiency principle to arbitrarily expand the scope of application for accelerating the payment of shareholders' obligations. First of all, enterprises in the initial stage are mostly faced with a shortage of liquid funds, and debts are not paid off in the short term, which is very common in commercial activities. If the creditor's capital contribution obligation is granted to speed up the claim for expiration, any creditor at any time requesting the shareholder not to fulfill the capital contribution obligation in advance according to the capital contribution period recorded in the company's articles of association will cause the company sponsor to involve unnecessary litigation. Although the promoters of the company supervise the capital contribution of the shareholders in accordance with the company's articles of association, the company sponsors are in a state of guarantee for all the capital contributions subscribed by other shareholders, and face many uncertain litigation risks. Seriously dampen the enthusiasm of the market entity to set up a company. Obviously, it is contrary to the legislative spirit of fully subscribing to the capital system, "reducing the threshold for entry and optimizing the business environment". Second, it is easy to trigger a litigation competition. Under the accelerated expiration system under bankruptcy procedures, the 
creditor's claims are settled in order and proportion. The Enterprise Bankruptcy Law has strict regulations and proper arrangements, and it is not easy to generate disputes between creditors. The litigation procedure arranges the claims of multiple creditors in full accordance with the mode of time competition. Whoever completes the proceedings first, first settles the settlement agreement, and completes the execution first, whoever gets priority compensation. In addition, if the debtor's company's book assets are too small, it may be difficult for creditors who file a lawsuit to obtain compensation. Once an accelerated expiration system is added to the lawsuit, the creditor can only rush to file a lawsuit and expose the defendant company and shareholders to litigation in order to protect their own interests. Again, it is easy to trigger false lawsuits. If the creditor who completes the lawsuit is given priority compensation, then the company that is in debt can arrange for the person to create a false lawsuit before the debt crisis is exposed. In a false lawsuit, even if the court decides that the defendant's shareholder's capital contribution obligation accelerates to expire, the shareholder's contribution amount falls into his own hands. After the completion of the false lawsuit, the company will completely become empty shells. At this time, the real creditors are difficult to defend their rights, whether through litigation or bankruptcy. If the real creditor can find the existence of a false lawsuit, but the appeal of the false lawsuit is extremely difficult, the creditor's interest is still unable to get timely protection. Finally, not giving creditors the obligation to fund the expiration of the claim for expiration will lead to the creditor's application to the court for bankruptcy. The author believes that such fear is not necessary. If the sponsor shareholders of each company are interested in maintaining the normal operation of the company, they will naturally repay the debt or even borrow the usury through various means. Or reach a debt repayment agreement with the creditors. Most creditors believe that it is more laborious and laborious to solve the problem by filing a bankruptcy lawsuit in the court. If the company is unable to pay off a certain specific debt, it means that the company has been insolvent, fully in line with the bankruptcy conditions, and let the company enter the bankruptcy process as soon as possible. Instead, it can reduce the complaints of all parties and free themselves from the debt dispute as soon as possible. A more efficient solution.

\section{The principle of autonomy of company law.}

The innovation of enterprise system and the need to adapt to market competition are the realistic basis of the principle of corporate governance autonomy. A company lacks creativity and innovation and cannot adapt to the cruel market competition. The trend of economic globalization will inevitably accelerate China's economic globalization, marketization, liberalization and openness. Therefore, it is necessary to innovate the company management system to meet the needs of market competition. The company was established by consensus among the promoter shareholders for a common business goal. By enacting the company's articles of association, the company is qualified as a legal entity, and the company's decision-making power and management rights are still implemented by the company's shareholders through the establishment of shareholders' meetings and the board of directors. Giving the company autonomous rights, to a certain extent, also gives the company's shareholders autonomy. Therefore, the 2013 Company Law must protect both corporate autonomy and shareholder autonomy. The establishment of a fully subscribed capital system is to respect corporate autonomy and shareholder autonomy. In 2013, the company's capital system reform removed the initial capital contribution limit of the shareholders and the minimum registered capital of the company, and canceled the capital verification procedure. The capital contribution period and the capital contribution method can be freely agreed by the shareholders. These reforms have reduced the unnecessary interference of administrative power and 
national will to the company's life, further expanding the space of corporate autonomy, respecting shareholder autonomy, shareholder freedom, and shareholder democracy. Strengthening the protection of shareholder autonomy has objectively promoted the pursuit of shareholders' maximization of their own interests. Inspired a large number of social personnel to invest in entrepreneurship, releasing the vitality of the market and meeting the needs of China's economic supply side structural reform. In the case of non-bankruptcy, the shareholders' contribution obligation accelerates the application of the maturity and deprives the shareholders of the capital contribution period. This is contrary to the principle of corporate autonomy and does not conform to the legislative spirit of fully subscribed capital.

\section{The principle of interest balance in company law.}

The principle of balance of interests means that the establishment of a corporate system requires a comprehensive assessment of the company's economic goals, social goals and social development impacts, and then analyzes and balances the various interests of the company and society, especially the excessive protection of specific interests. Article 1 of the "Company Law" of China stipulates the legislative purpose of the company law. It is equally important to protect the legitimate rights and interests of creditors and protect the interests of companies and shareholders. Between the protection of shareholders' interests and the protection of creditors' interests, the principle of interest balance in company law is not to make trade-offs and biases between the two, but to achieve balanced protection of shareholders' interests, creditors' interests, and company interests, and to achieve overall social and economic benefits. Maximize. In order to protect the interests of creditors, the shareholder's contribution obligation in non-bankruptcy cases is allowed to accelerate the application of the maturity system, but the shareholders' term benefits are deprived. This is a principle of balance of interests that is a serious violation of company law. Scholars Chen $\mathrm{Su}$ and Zhao Wanyi also pointed out that paying too much attention to the protection of creditors is a matter of contract law and does not conform to the concept of the Company Law. Scholars who support the accelerated maturity of shareholders' contributions under non-bankruptcy situations hope to give creditors a remedy when the company is insolvent. In fact, in the face of the long-term funding period, the amount of the capital contribution is too large, the failure to perform or the full implementation of the capital contribution obligation cannot solve the problem of the debt due, the protection of the creditor's interests can have many ways, there is no need to sacrifice the shareholders' time limit. interest. For example: play the warning effect of the bankruptcy reconciliation system and the bankruptcy reorganization system, set up the court's inquiry procedure, improve the collection system, and improve the company's credit information system.

\section{Conclusion}

The reform of the capital system of the Company Law in 2013 drove the vitality of the market and stimulated entrepreneurial innovation. Because China's social credit mechanism, creditor's rights and interest's protection, transaction security and other supporting systems are still not perfect, the fully subscribed capital system has left many legislative gaps and shortcomings in the application of judicial practice. The issue of protecting the interests of creditors caused by long-term shareholder funding deadlines is very prominent. In the case of non-bankruptcy, can the shareholders' capital contribution obligation accelerate the expiration, and can the creditor ask the shareholders to fulfill the capital contribution obligation in advance? This problem has caused confusion in the legal profession. The accelerating maturity system of shareholders' funding 
obligations cannot be applied in non-bankruptcy situations. The author analyzes the legal basis that the shareholders' contribution obligation cannot accelerate the expiration.

\section{References}

[1] Guo Fuqing. Reconstruction of China's Corporate Capital System and Risk Prevention[J]. Finance and Economics Law, 2015(5): 33-34.

[2]Zhao Xudong. Capital Legal Responsibility under the Reform of Capital System[J].Legal Research,2014(5):19-23.

[3] Guan Xiaofeng. Research on Capital Law of the Company [N]. China Business News, 2014-6-11(3).

[4] Lei Xinghu, Xue Bo. Review and revision of company law [J]. Xinjiang Social Science Forum, 2014

(4): 45-50.

[5] Gan Peizhong, Zhou You. Semantic Interpretation of Registered Capital Registration and System Deconstruction[J]. China Business Management Research, 2013(5): 8-12.

[6] Chen Su. The theory analysis and normative division of capital credit and asset credit [J]. Global Law Review, 2015(1): 41-54.

[7] Chen Su. Multiple effects of paid-in capital and its safeguard measures [J]. J. Law, 2014 (12): 47-56.

[8]Zhao Xudong. Capital Reality and Capital Verification and Exemption[J]. China Business Management Research, 2014(7): 14-15.

[9] Du Jun. The Evolution of Corporate Capital System Principles and New Judicial Subjects[J]. Law Application, 2014(11): 2-12.

[10] Huang Hui. The legitimacy of the company's capital system reform based on the legal and economic analysis of creditor protection function [J]. China Law, 2015 (6): 159-178.

[11] Feng Guo, Nan Yumei. On the shareholder's supplementary liability and the sponsor's capital enrichment responsibility [J]. People's Justice, 2016 (4): 33-37.

[12] Zhang Hengzhu et al. Creditor litigation relief under the capital account system [J]. People's Justice, 2016 (16): 96-102.

[13] Liang Shangshang. Supplementary Liability of Unclaimed Shareholders to Corporate Creditors [J]. Chinese and Foreign Law, 2015 (3): 649-664.

[14] Wang Zejian. The principle of debt law [M]. Beijing: Peking University Press, 2013: 60.

[15] Gu Chunde, Shi Wei. History of Western Legal Thoughts (Third Edition) [M]. Beijing: China Renmin University Press, 2009: 350.

[16]Lian Jianbo et al. Analysis and Suggestions on American Corporate Governance Principles (Vol. 1) [M]. Beijing: Law Press, 2006: 128

[17] Wu Rihuan. Korean company law [M]. Beijing: China University of Political Science and Law Press, 2000:324. 